\title{
Riau Provincial Local Governments and Riau Malay Customary Law in the Perspective of Karl Jaspers' Theory of Existence
}

\author{
Hengki Firmanda \& Juhansar \\ Universitas Riau dan Universitas Teknologi Yogyakarta
}

\begin{abstract}
This study aims at analyzing the relationship between Riau provincial governments and Riau Malay Customary Law (LAM Riau) using Jaspers' theory of existence. The data of this study are qualitative ones using the sociological law as the approach. Riau Malay customary law is the norm regulates the manner of behavior of the Malay people. Riau Malay customary law is a law-based-community. It means, the law is conserved and raised its existence jointly. The local governments have a very important role in maintaining its existence. Local governments (executive and legislative) and customary institution are defined as state organizers.
\end{abstract}

\begin{abstract}
Abstrak
Penelitian ini bertujuan untuk menganalisis tentang hubungan pemerintah daerah Provinsi Riau dan hukum adat melayu Riau menurut teori eksistensi Jasper. Hukum adat melayu Riau merupakan norma yang mengatur tentang tata cara bertingkah lakunya orang melayu. Hukum adat melayu Riau adalah hukum yang berbasis pada komunitas (law based comunity), sehingga hukum dilestarikan secara bersamasama, dan diangkat eksistensinya secara bersama-sama pula. Pemerintah daerah sangatlah berperan penting dalam menjaga eksistensi hukum adat melayu Riau. Pemerintah daerah diartikan sebagai penyelenggara negara dalam tingkat daerah ialah Eksekutif, Legislatif dan Lembaga Adat Melayu Riau.
\end{abstract}

Keywords: Local Governments, Existence, Riau Malay Customary Law

Author correspondence

Email: hengki.firmanda@gmail.com; juhansar@uty.ac.id.

Available online at http://journal.iaingorontalo.ac.id/index.php/au/index 


\section{A. Introduction}

The law is the rule set by the legitimated leader ${ }^{1}$ but it is along with the community. Law as a moral category is similar to justice. The law binds all people's justice and desire, thus the law and justice are understood in the sense of equality and commonality ${ }^{2}$. The human desire for the coming of law is to achieve justice. Therefore, justice is supposed to exist and absorb in the law. The existence of the national law is based on the multicultural consensus of the Indonesian nation. The written national law set consensually by the executive and the legislative called statute and/or regulation. Indonesia is a law state, however, the questions whether the law meets the ideals of the national law or not, hence it is necessary to examine it carefully ${ }^{3}$. The ideals of the national law should be in line with the ideology of the Indonesian nation, Pancasila, and its materialist causation. Its materialist causations are the variation of the Indonesian socio-cultural background.

The traditional customary law is the law existed before the independence of Indonesia which is still implemented by some people and/or communities. Customary law is a rule of human habits in community life which basically starts from values that grow, develop, and accepted by the community ${ }^{4}$. The existence of the traditional customary law can be seen in the Article 18B paragraph (2) of the Constitution. It is mentioned that the state recognizes and respects the unity of indigenous and tribal peoples along with their traditional rights as long as it is alive and in accordance with the development of the society and the principle of the Unitary State of the Republic of Indonesia. The Constitution states that customary law is the laws which should be used as a source of guidance for living in society and for drafting national legislation material ${ }^{5}$.

${ }^{1}$ Theo Huijbers, Filsafat Hukum dalam Lintasan Sejarah, Yogyakarta: Kanisius, 1982, p. 273.

${ }^{2}$ Satjipto Rahardjo, Teori Hukum, Yogyakarta: Genta Publishing, 2010 p. 45.

${ }^{3}$ A. Hamid S. Attamimi, Fungsi Ilmu Perundang-Undangan dalam Pembentukan Hukum Nasional, makalah disampaikan pada ceramah ilmiah di Fakultas Hukum Universitas Islam Assyafiah, Jakarta 17 Maret 1989, P. 5

${ }^{4}$ Firmanda, Hengki, "Hukum Adat Masyarakat Petapahan dalam Pengelolaan Lingkungan sebagai Upaya Pemenuhan Hak Masyarakat Adat", Fikri: Jurnal Kajian Agama, Sosial dan Budaya, Vol. 2, No. 1 Juni Tahun 2017, p. 8

${ }^{5}$ Maladi, Yanis, "Eksistensi Hukum Adat dalam Konstitusi Negara Pasca Amandemen", Mimbar Hukum, Vol. 22, No. 3 Oktober Tahun 2010, p. 456 
Furthermore, the regulation and/or the law emphasizes the existence of the traditional customary law can also be seen in the Act Number 5 of 1960 on Basic Agrarian Principles or Peraturan Dasar Pokok-Pokok Agraria (UUPA) and in the Act Number 6 of 2014 on Villages. Article 5 of the UUPA states that the agrarian law implemented on the earth, water, and space is a customary law. The village law governing the traditional customary is in Chapter XIII, from Article 96 to Article 111. The village law states that the Government, provincial and district governments undertake the structuration on the unity of the traditional customary law peoples and set it as a traditional customary law village (Article 96 of Village Law). The customary law village strengthening is also included in some Constitutional Court's decisions. The Constitutional Court's decision among others is in the Decision of the Constitutional Court Number 35/PUU-IX/2012. The decision strengthens the customary law people ownership on the forest where it is no longer as the state control anymore. This shows that strengthening the law presents in strengthening the existence of the traditional customary law peoples.

The recognition of customary law is also regulated in the Article 41 of MPR No. XVII/MPR/1998 on Human Rights II Charter of Human Rights and in the Article 6 Paragraph 2 of Act Number 39 of 1999 concerning on Human Rights, which states that the cultural identity of traditional communities, including rights to communal land is protected, in line with the times. This legislation was in the post-reformation era where its regulation essence stipulates the existence of indigenous peoples that must be recognized by the state. Indeed, this concept was applied also in the new order era 6 .

One of the provinces in Indonesia which still maintains its Malay custom is Riau Province. The identity of Riau Malay indigenous peoples is an integral part of the natural community and the religious-metaphysical community.7 Malay custom was inherited by the Malay ancestors where it still exists in all villages in that province. Indeed, it can be found traditional customary law people also who are

\footnotetext{
${ }^{6}$ Anggoro, Teddy, "Kajian Hukum Masyarakat Hukum Adat dan HAM dalam Lingkup Negara Kesatuan Republik Indonesia”, Jurnal Hukum dan Pembangunan, Vol. 35, No. 4, Tahun 2006, p. 491492

7Thamrin, Husni, "Rekontruksi Ecoreligius Orang Melayu Solusi Penyelamatan Lingkungan", AlFikra: Jurnal Ilmiah Keislaman, Vol. 16, No. 1 Tahun 2017, p. 120
} 
still living in the jungle such as Sakai and Talang Mamak tribes. Riau Malay people spread throughout the region to remote islands, including in the Riau Province and Riau Islands (formerly these two provinces are one). The rules governed by Riau Malay customary law are to regulate the customary law on land, the customary law on marriage, the customary law on family, the customary law of inheritance, the customary law on trafficking, the customary law on crime, and the customary law traditional titles.

Currently, Riau Malay customary law has decreased its existence. The decline of the existence of Riau Malay customary law may be caused by the influx of the outside cultures erodes the local culture and the implementation of the Indonesian law generally. The Indonesian law implementation forces Riau Malay customary law to get only a small portion in regulating its traditional people. Furthermore, the local governments also have less support and policy to sustain and maintain the existence of the customary law. Indeed, those problems are going to be discussed deeply in this article using Jaspers' theory of existence.

This is a qualitative research using the sociological law as a type. Sociological law research is an empirical research finding laws in the empirical facts. This research was conducted at the Governor Office of Riau Province and at the Institute of Malay Customary of Riau or Lembaga Adat Melayu Riau (LAM Riau). There were two kinds of data used in this research, namely primary and secondary data. Primary data collected by doing observation and interview. There were three persons chosen as samples to be interviewed, two persons from the Bureau of Justice and Human Rights of Riau Province, Head of Bureau of Justice and Human Rights of Riau Province and an officer of sub-division of the local regulation, and one person from LAM Riau, Head of Institute of Malay Customary of Riau. Secondary data were data taken through library research. The technique used was finding the main references related to Local Regulation, existence and traditional Malay customary law. 


\section{B. Riau Provincial Local Governments and Riau Malay Customary Law in the Perspective of Karl Jaspers' Theory of Existence}

Jaspers divides his philosophical thought into three ways, namely: weltorientierung (world orientation), existenzerhellung (elucidation existence enlightenment), and metaphysik (metaphysics) ${ }^{8}$. Every elucidation existence produces a world orientation. Metaphysics may only exist based on world orientation and the elucidation existence. The orientation of the world takes place in positive science. The understanding of the positive science is a necessary condition for achieving the philosophical goals. Here is where people reach the limits of the positive science.

The existence exists because weltorientierung has reached its limit situation, so "existing" seeks to display its existence. If so, then "what the existence is?" Soemargono mentions that the existence is the effort to manifest oneself in the world and to overcome the world ${ }^{9}$. The existence is presenting the self along with the outside world in order to be recognized by the outside world. If the self has been shown to the outside world, then the self will be different from what is in the outside world. It means a man is trying to show himself indirectly as the way he has. Mudhofir concludes that the existence that I am the self, the unique self. The existence offers new possibilities. It is the expression and the reflection of the total freedom as the core of a man. The existence can be lived, illuminated, and communicated to others through philosophical reflection ${ }^{10}$.

Jaspers stated that the existence is the most precious and authentic "thing" in a man ${ }^{11}$. The existence is the reflection of the total freedom of a man ${ }^{12}$. To understand Jaspers' theory of existence, one should analyze the situation at first. The situation cannot be avoided and eliminated. The situation according to Jaspers is the situation where a man initially hopes for the objectivity and the certainty, nevertheless the fact shows that a man is unable to be. It is because a man has

\footnotetext{
${ }^{8}$ Karl Jaspers, Philosophy Volume 2, Translated by E. B. Ashton, Chicago and London: The University of Chicago Press, 1969, pp. 68-72

${ }^{9}$ Soemargono, Filsafat Abad 20, Yogyakarta: Tiara Wacana, 1988, p. 144

${ }^{10}$ Ali Mudhofir, Kamus Filsafat, Yogyakarta: Pustaka Pelajar, 2001 p. 261

${ }^{11}$ Karl Jaspers, Philosophy Volume 2, Translated by E. B. Ashton, Chicago and London: The University of Chicago Press, 1969, p. 154

${ }^{12}$ K. Bertens, Filsafat Barat Abad XX, Inggris-Jerman, Jakarta: Gramedia, 1990, p. 132
} 
limitation. However, a man still has other next situation where he/she could reach the real existence exists in him/herself. This situation is existentially inside the self itself ${ }^{13}$.

A man exists in the world weltorientierung-ly, but this is not the existence yet, because the existence does not mean as physical or empirical existence. If the existence exists only as it is, it is supposed to arrive at the boundary situation that is a man must die. Therefore, one is required to understand the existence not just as the way it is or the existence of dasein, but going beyond the boundary situation that limits the existence of dasein. The existence is a man decision where a man wishes to be immortal beyond the boundary situation of dasein. Hence, through decisions, a man creates his/her own existence.

A man in a social life needs regulation. The regulation should be in line with the ways of the life. The way of life will be established more if it is conducted repeatedly then becomes a habit. This habit is practiced continuously then becomes a custom. The custom grows up in and along with human's life, so it could become a regulation so-called traditional customary law. The people will be wellknown by how closed their relation to the traditional customary law. It means that the thing differs ones with others is the traditional customary law.

The law comes from the soul of the nation which has been entwined in the life of society repeatedly and continuously ${ }^{14}$. Savigny mentions that the nation in this world is divided into several kinds, so each nation has the soul of the selfnation. The soul of the nation is certainly different from one another. The most popular phrase expressed by Savigny is Das Recht wird nicht gemacht, est is und wird mit dem volke (the law is not created but it grows and develops along with the people in the daily life ${ }^{15}$. According to Marwan that Savigny tends to convey that the law is not created but it is found in society and/or people daily life. He glorifies the glory of the law in the past and assumes that the role of jurists is more important than the legislators. Finding the law is by finding the people and in the

\footnotetext{
${ }^{13}$ Harun Hadiwijono, Sari Sejarah Filsafat Barat 2, Yogyakarta: Kanisius, 2005, p. 169

${ }^{14}$ Nomensen Sinamo, Filsafat Hukum, Jakarta: Permata Aksara, 2014, p. 56

${ }^{15}$ Lili Rasjidi and Ira Thania Rasjidi, Dasar-Dasar Filsafat dan Teori Hukum, Bandung: Citra Aditya Bakti, 2007, p. 65
} 
people, it is found volkgeist (soul of the people) ${ }^{16}$. Through this way, the law becomes linear with its people, and the people are in line with the laws. The law is in accordance with its nature where it is continuously growing and developing ${ }^{17}$. The way to eliminate the law is by eliminating the people. The law is deemed no longer relevant to the people if the people soul is gone.

The laws excavated from the people are the laws correspond to the wishes and the lives of the people. In Indonesia, the laws coincide with the people, traditional customary law, are often found from Aceh to Papua. Regional differences show legal differences because the law is in the soul of the people. It means, the contents of the law are determined by the association and the interaction of the people ${ }^{18}$. The diversity in Indonesia shows the differential rule of laws where each region does not experience the same development ${ }^{19}$. Therefore, the Indonesian government should have a priority on the customary law because the laws are unable to be used as a tool to change the peoples or community 20.

One of the largest is Riau Malay traditional customary law. Riau Malay customary law spreads not only in Riau province but also Riau Island. The people who follow the Riau Malay customary law called Malay people. The identity of Riau Malay people mentioned by the Head of Institute of Riau Malay Customary Law (LAM Riau) is the man who follows Riau Malay customary law, Malay language, and Muslim ${ }^{21}$. The main foundation of Malay people is Islam except for the indigenous Malay who converts into another belief, but he/she is still considered as Malay. In short, Malay people are identical with Islam. Islam becomes the main guideline for Malays in determining the behavior of the people. Islam is the noble

\footnotetext{
16Marwan, Pengantar Ilmu Hukum, Jakarta: Ghalia Indonesia, 2004, p. 124

${ }^{17}$ Abubakar, Lastuti, "Revitalisasi Hukum Adat sebagai Sumber Hukum dalam Membangun Sistem Hukum Indonesia”, Jurnal Dinamika Hukum, Vol. 13, No. 2, Mei Tahun 2013, p. 322

${ }^{18}$ Ridwan, Khudzaifah Dimyati and Aidul Fitriciada Azhari, "Perkembangan dan Eksistensi Hukum Adat: dari Sintesis, Transplantasi, Integrasi Hingga Konservasi”, Jurisprudence, Vol. 6, No. 2, September Tahun 2016, p. 109

${ }^{19}$ Syamsudin, M, "Beban Masyarakat Adat Menghadapi Hukum Negara”, Jurnal Hukum Ius Quia Iustum, Vol. 15, No. 3, Juli Tahun 2008, p. 347

${ }^{20}$ Muslih, M, "Memposisikan Manusia sebagai Titik Sentral dalam Berhukum (Menelusuri Sebagian Pemikiran Prof. Dr. Satjipto Rahrdjo, SH dalam Memahami Hukum Indonesia”, Jurnal Lex Specialis, No. 15 Juni Tahun 2012, p. 33

${ }^{21}$ Interview with Head of Institute of Riau Malay Customary Law, Mr. Al Azhar
} 
values in determining the law for the Malays, so the law according to the Malay is the law based on the Quran and the Sunnah.

The hallmark of Riau region is the rules or laws of Malayness. The existence of the customary law of Riau Malay has not shown that the Malay awakened its existence. The existence of Riau Malay Customary Law is the only about the physical existence of Riau Malay customary law. In other words, Riau Malay customary law is just in the stage of dasein or weltorientierung. The existence of Riau Malay Customary Law empirically has not shown the existence of Malay itself. The manifestation of existence is like what Jaspers said that the existence is the soul $^{22}$.

Soemargono mentions that the existence is an attempt to manifest oneself in the world and with that way; one is able to undergo the world ${ }^{23}$. The existence of Riau Malay customary law is an effort to realize Riau Malay people in the world and a way to undergo the world life by answering the existing problems. It means the existence of Riau Malay customary law should be in line with the unification of the outside world. The existence is the bridge to connect the intention with the extension. If the intention of Riau Malay customary law has shown its existence on the extension, the customary law of Riau Malay becomes different from what already exists in the extension (the outside world).

The existence is the unique differentiator to the outside world, so the essence of existence is the real I myself. Indicating the existence of Riau Malay customary law means affirming the existence of Riau Malay customary law in itself by having the unique distinctive outside world. The existence of Riau Malay customary law is in itself, which then needs to be revealed by Riau provincial government. If it has been disclosed, it is necessary to keep and maintain its existence to exist always in the extension world.

According to the theory of existence proposed by Jaspers that Provincial Government of Riau Province cannot be categorized yet as the government has been maintaining the existence of Riau Malay customary law. The government has just arrived on the stage of dasein or weltorientierung. It means the government

\footnotetext{
${ }^{22}$ Hamersma, Harry, 1983, Tokoh-Tokoh Filsafat Barat Modern, Jakarta: Gramedia, 1983, p. 119

${ }^{23}$ Soemargono, Filsafat Abad 20, Yogyakarta: Tiara Wacana, 1988, p. 144
} 
has just established the institution where it is unable to form Riau Malay customary law because it is not given the flexibility in acting strategically. The executive local government headed by the Governor of Riau Province, through the interview with the Head of Legal and Human Rights Bureau and Local Regulatory Sub-Division stated that Riau Provincial Government institution has not been focused on reviving and maintaining the existence of Riau Malay Customary Law. The local governments only play a role in supporting the socialization and budgeting.

Local governments proposed the draft of local regulations that later becomes the reference for the local regulations. The goodwill of the government can also be seen from the struggle of the government in establishing local laws based on Riau Malay customary law. Data obtained from the Legal and Human Rights Bureau about the draft of Local Regulation in the form of Riau Governor proposal in 2015 states that there are three proposals namely (a) the draft of Local Regulation on Spatial Planning (RTRW) Riau Province 2014-2032; (b) the draft Local Regulation on the Aviation Operational Safety Area (KKOP) and Noise Area Boundaries (BKK), and; (c) the draft of Local Regulation on the Management of Sultan Syarif Hasyim Forest Park (Tahura SSH). Those three drafts of the Local Regulation have not been materially laden with Riau Malay customary law. The government's commitment to the vision and the spirit of the regional autonomy remain to be questioned again. The hope is that the government as a breakthrough should make and conduct all policy affairs based on Riau Malay customary law.

Council of Regional People's Representatives (DPRD) of Riau Province is an institution represents and accommodates the people aspirations. Council of Regional People's Representatives (DPRD) of Riau Province has three functions namely the legislation function, budgeting function, and supervisory function. One of the most important functions that Council of Regional People's Representatives (DPRD) of Riau Province has related to Riau Malay customary law is to create Local regulation. Legislation becomes an important law for the region as the basis for conducting regional affairs.

Council of Regional People's Representatives (DPRD) of Riau Province through the function of legislation has proposed the formation of the Local 
Regulation Number 1 of 2012 about Riau Malay Customary Law Institution on January 18, 2012. In 2015, as seen in the Decree of Riau Province Parliament Number 01/KPTS/DPRD/2015 about the Formation of Local Regulation Program of Riau Province in February 9, 2015, mentioned that among eleven drafts on Local Regulation of Council of Regional People's Representatives (DPRD) of Riau Province, the only two drafts relate to Riau Malay Customary Law. The two drafts are (a) the draft of Local Regulation concerning on the Preservation and the Development of Riau Malay Culture and Local Wisdom with the new status of 2015 proposed, and (b) the draft of Local Regulation on Ulayat Land and Its Utilization. The two Regional Regulations were successfully approved on December 23 ${ }^{\text {rd }}, 2015$ as Riau Provincial Regulation No. 9 of 2015 concerning on the Preservation of Riau Malay Culture and Riau Provincial Regulation No. 10 of 2015 concerning on the Customary Land and Its Utilization.

Council of Regional People's Representatives (DPRD) of Riau Province in 2015 has only a little commitment in lifting the draft of the local regulations, although in principle, Council of Regional People's Representatives (DPRD) Riau Province is able to create more drafts on local regulation in 2015. Council of Regional People's Representatives (DPRD) of Riau Province is more committed to maintaining the existence of Riau Malay customary law than the Governor of Riau. The data of Riau Provincial Regulation from 2000 to May 2015 show that there were 177 Local Regulations ever existed in Riau Province and 155 of them which are still valid nowadays. From 155 Local Regulations, the only 1 Local Regulation mentions about Riau Malay customary law, namely Local Regulation Number 1 of 2012 on Riau Malay Customary Law Institution. There is one Local Regulation mentions about Riau Malay Customary Law explicitly, namely the Local Regulation Number 8 of 2014 on the Environmental Management and the Environmental Law Arrangement which was approved on September 8, 2014.

The data above show that from 2000 to May 2015 with the number of 155 valid Local Regulations in Riau Province, the only 2 governing Riau Malay Customary Law. If it is percentage, the only 1.3\% of the 155 (100\%) Local Regulations govern Riau Malay Customary Law. It means that from the regulation side, the local governments are considered having less commitment to maintaining 
the existence of Riau Malay customary law. The policies of the local governments have not supported Riau Malay customary law. The local governments should create the policies to support the existence of Riau Malay customary law. Not only to support but also to implement that policies for the sake of Riau Malay customary law existence.

After the enforcement of the Local Regulation Number 1 of 2012 on Riau Malay Customary Institution on January 18, 2012, the Malay Customary Institution (LAM) Riau seeks to preserve the Malay customary law. Riau Malay Customary Law (LAM Riau) is an institution formed to accommodate, guide, develop, and implement the values of Riau Malay traditional Culture ${ }^{24}$. The existence of LAM Riau institution aims at exploring, fostering, preserving, nurturing and developing custom values and socio-cultural values as a foundation for strengthening the identity of Malay people. LAM Riau also aims at protecting and defending the traditional and constitutional rights of Riau Malay indigenous peoples and sociocultural values for the benefit of increasing the outward and inner welfare. LAM Riau should not be the only institution but empower Malay indigenous people and their socio-cultural values for the sake of getting better civil society (Article 6 of Local Regulation Number 1 of 2012 on Riau Malay Customary Institution). The task of LAM Riau is to spearhead the preservation of Malay culture in $\mathrm{Riau}^{25}$ and to maintain the existence of Riau Malay culture.

The preservation of Riau Malay customary law for LAM Riau is to protect, develop and utilize the Riau Malay customary law ${ }^{26}$. The effort to preserve Riau Malay customary law is not supported by material legal instruments of customary law. It means that local governments only establish customary law institution (LAM) Riau without any rules supporting its existence. The local regulations related to LAM Riau institutionalization have not been able to revitalize the local regulations. Riau Malay customary law is only used as a compliment by the local

\footnotetext{
${ }^{24}$ Bachtiar, Maryati, "Peranan Lembaga Adat Melayu Riau dalam Penyelesaian Konflik Tanah Ulayat di Provinsi Riau", Jurnal Hukum Respublica, Vol. 16, No. 2 Tahun 2017, p. 306

${ }^{25}$ Zainuddin, M, "Mekanisme Lembaga Adat Melayu Riau dalam Melestarikan Wisata Budaya di Provinsi Riau", Jurnal Agregasi, Vol. 6, No. 1 Tahun 2018, p. 93

${ }^{26}$ Interview with Mr. Al Azhar, the Head of LAM Riau
} 
governments to be said as not negligent in maintaining the existence of Malay customary law of Riau.

The strategic steps taken by LAM Riau to maintain the existence of Riau Malay customary law is using the Law Number 6 of 2014 on the Village Regulation as an approach. LAM Riau through the Village Law initiates the establishment of an indigenous custom village. LAM Riau proposes to each region to have a draft of local regulation on the indigenous custom village, as long as there are genealogical

proximity and people as a homogeneous society. The strategic approach taken by LAM Riau is considered success where almost every region has its own indigenous custom village, such as in Siak and Rokan Hulu 27.

When the indigenous custom village has been established in every region, the indigenous custom villagers form their structures formation. If the indigenous custom village structure formed, the customary law order is established as well. The indigenous custom villages that have been established and formed will re-up Riau Malay customary law. The enforcement of customary law empowers the people to implement it in the daily life. This is the success of Riau Malay people including local governments and LAM Riau in maintaining the existence of Riau Malay customary law as like Jaspers' theory of existence.

In addition, the strategic approach undertaken by LAM Riau in establishing indigenous customary villages supported by the police. The rise of the existence of Riau Malay customary law will help the police in solving and overcoming the cases in society. For example, if there is a legal issue then the indigenous custom peoples should resolve it first in accordance with the customary law before handled by the police or even the case is closed under the customary law.

\section{Conclusion}

The relationship between Riau provincial governments and Riau Malay customary law in maintaining the existence of customary law according to Jaspers' theory of existence are (a) the local government has not been doing maximal efforts in maintaining the existence of Riau Malay customary law as it is proved by

\footnotetext{
${ }^{27}$ Interview with Mr. Al Azhar, the Head of LAM Riau
} 
the lack of initiatives in creating policies to support Riau Malay Customary Law; (b) Council of Regional People's Representatives (DPRD) of Riau Province in maintaining the existence of Riau Malay customary law has established Local Regulation Number 1 of 2012 on Riau Malay Customary Institution and in 2015, it submitted 11 drafts of Local Regulation and the only 2 of them about Riau Malay customary law. The initiative of Council of Regional People's Representatives (DPRD) of Riau Province is slow but at least there is an initiative to maintain the existence of Riau Malay customary law; and (c) Riau Malay Customary Institution (LAM Riau) has maintained the existence of Riau Malay Customary Law by trying to preserve the Riau Malay Customary Law. Conservation means as protection, development and utilization. LAM Riau realized that its institution existence is only recognized in the form of institutional existence because it is mentioned in Local Regulation Number 1 of 2012 on Riau Malay Customary Institution; however, the existence of material law source of Riau Malay customary law has not got meaningful support yet from the local governments. LAM Riau conducted Strategic Steps in terms of Riau Malay customary law preservation using the Laws Number 6 of 2014 on the Village as an approach. The laws tend to support the establishment of indigenous custom villages. The established indigenous custom villages support and maintain the existence of Riau Malay customary law existence.

\section{References}

Abubakar, Lastuti, "Revitalisasi Hukum Adat sebagai Sumber Hukum dalam Membangun Sistem Hukum Indonesia”, Jurnal Dinamika Hukum, Vol. 13, No. 2, Mei Tahun 2013, p. 319-331.

Anggoro, Teddy, "Kajian Hukum Masyarakat Hukum Adat dan HAM dalam Lingkup Negara Kesatuan Republik Indonesia", Jurnal Hukum dan Pembangunan, Vol. 35, No. 4, Tahun 2006, p. 487-498.

Attamimi. A. Hamid S. 1989, Fungsi Ilmu Perundang-Undangan dalam Pembentukan Hukum Nasional, makalah disampaikan pada ceramah ilmiah di Fakultas Hukum Universitas Islam Assyafiah, Jakarta 17 Maret 1989.

Bachtiar, Maryati, "Peranan Lembaga Adat Melayu Riau dalam Penyelesaian Konflik Tanah Ulayat di Provinsi Riau", Jurnal Hukum Respublica, Vol. 16, No. 2 Tahun 2017, p. 298-312.

Bertens, K, 1990, Filsafat Barat Abad XX, Inggris-Jerman, Jakarta: Gramedia. 
Firmanda, Hengki, "Hukum Adat Masyarakat Petapahan dalam Pengelolaan Lingkungan sebagai Upaya Pemenuhan Hak Masyarakat Adat”, Fikri: Jurnal Kajian Agama, Sosial dan Budaya, Vol. 2, No. 1 Juni Tahun 2017, p. 1-26.

Hadiwijono, Harun, 2005, Sari Sejarah Filsafat Barat 2, Yogyakarta: Kanisius.

Hamersma, Harry, 1983, Tokoh-Tokoh Filsafat Barat Modern, Jakarta: Gramedia.

Huijbers, Theo, 1982, Filsafat Hukum dalam Lintasan Sejarah, Yogyakarta: Kanisius.

Jaspers, Karl, 1969, Philosophy Volume 2, Translated by E. B. Ashton, Chicago and London: The University of Chicago Press.

Maladi, Yanis, "Eksistensi Hukum Adat dalam Konstitusi Negara Pasca Amandemen", Mimbar Hukum, Vol. 22, No. 3 Oktober Tahun 2010, p. 450464.

Marwan, 2004, Pengantar Ilmu Hukum, Jakarta: Ghalia Indonesia.

Mudhofir, Ali, 2001, Kamus Filsafat, Yogyakarta: Pustaka Pelajar.

Muslih, M, "Memposisikan Manusia sebagai Titik Sentral dalam Berhukum (Menelusuri Sebagian Pemikiran Prof. Dr. Satjipto Rahrdjo, SH dalam Memahami Hukum Indonesia", Jurnal Lex Specialis, No. 15 Juni Tahun 2012, p. 28-39.

Peraturan Daerah Nomor 1 Tahun 2012 tentang Lembaga Adat Melayu Riau.

Rahardjo, Satjipto, 2010, Teori Hukum, Yogyakarta: Genta Publishing.

Rasjidi, Lili dan Ira Thania Rasjidi, 2007, Dasar-Dasar Filsafat dan Teori Hukum, Bandung: Citra Aditya Bakti.

Ridwan, Khudzaifah Dimyati and Aidul Fitriciada Azhari, "Perkembangan dan Eksistensi Hukum Adat: dari Sintesis, Transplantasi, Integrasi Hingga Konservasi", Jurisprudence, Vol. 6, No. 2, September Tahun 2016, p. 106115.

Sinamo, Nomensen, 2014, Filsafat Hukum, Jakarta: Permata Aksara.

Soemargono, 1988, Filsafat Abad 20, Yogyakarta: Tiara Wacana.

Syamsudin, M, "Beban Masyarakat Adat Menghadapi Hukum Negara", Jurnal Hukum Ius Quia Iustum, Vol. 15, No. 3, Juli Tahun 2008, p. 338-351.

Thamrin, Husni, "Rekontruksi Ecoreligius Orang Melayu Solusi Penyelamatan Lingkungan”, Al-Fikra: Jurnal Ilmiah Keislaman, Vol. 16, No. 1 Tahun 2017, p. 99-136.

Undang-Undang Dasar 1945.

Undang-Undang Nomor 5 Tahun 1960 tentang Peraturan Dasar Pokok-Pokok Agraria.

Undang-Undang Nomor 6 tahun 2014 tentang Desa.Zainuddin, M, "Mekanisme Lembaga Adat Melayu Riau dalam Melestarikan Wisata Budaya di Provinsi Riau", Jurnal Agregasi, Vol. 6, No. 1 Tahun 2018, p. 92-107. 